\title{
«AMnesia In Fancy Dress»: IL Pageant in Between The Acts di Virginia WoOlf E IN Wigs on the Green di Nancy MITFORD
}

\begin{abstract}
Il saggio si pone come obiettivo l'analisi della rievocazione storica, il pageant, e del suo significato all'interno di due romanzi inglesi dell'interwar period: Between the Acts (1941) di Virginia Woolf e Wigs on the Green (1935) di Nancy Mitford. Il pageant ha rivestito un ruolo di primo piano nell'Inghilterra degli anni compresi fra le due guerre, assurgendo a simbolo della tradizione inglese e della Englishness, e trovando, inoltre, un forte riscontro nella letteratura di quel periodo. In Between the Acts, la rievocazione storica messa in scena da Miss La Trobe nel cuore della campagna inglese, sul prato di Pointz Hall, è il riflesso del caos ineluttabile che contraddistingue la condizione umana nel mondo moderno e del profondo senso di solitudine e di isolamento della società inglese sull' orlo della Seconda Guerra Mondiale. Mitford utilizza invece il pageant come strumento per smascherare l'inconsistente ideologia nazionalista del fascismo inglese di quegli anni, considerata dalla scrittrice solo vuota retorica priva di uno scopo concreto, e rappresentata, in Wigs on the Green, dal personaggio di Eugenia Malmains, la più ricca ereditiera inglese - versione romanzesca della sorella della scrittrice, la fascista Unity Valkyrie - fervente sostenitrice di Captain Jack e delle Union Jackshirts, partito fascista immaginario basato sulla British Union of Fascists di Sir Oswald Mosley. Partendo da una breve introduzione del pageant e del ruolo che riveste nella letteratura inglese degli anni ' 30 , si passa poi alla sua contestualizzazione all'interno delle opere di queste due scrittrici, focalizzandosi, in particolare, sul significato che assume in relazione al quadro storico-politico, culturale e sociale.
\end{abstract}

This essay aims at analysing the role of the pageant within two novels of the interwar period: Virginia Woolf's Between the Acts (1941) and Nancy Mitford's Wigs on the Green (1935). Pageants have played a fundamental role in interwar England as symbols of both the English tradition and Englishness, also becoming the focus of 1930s English literature. In Between the Acts, Miss La Trobe's historical pageant performed «in the heart of the [English] country», on the lawn of Pointz Hall, shows the inescapable chaos of the modern human condition and the sense of loneliness and isolation of English society on the brink of WWII. Mitford, instead, uses the pageant to unmask the insubstantial ideology of interwar English fascism, dismissed by her as «empty rhetoric», and represented, in Wigs on the Green, by the figure of Eugenia Malmains, «England's largest heiress» - the fictional version of Nancy's fascist sister, Unity Valkyrie - and an ardent supporter of Captain Jack and the Union Jackshirts movement, the fictitious equivalent of Sir Oswald Mosley's British Union of Fascists. After a brief introduction on the function of the pageant in 1930s English literature, I move to its contextualisation in the aforementioned novels, focusing in particular on its meaning within the historical, cultural and social milieu. 


\section{INTRODUZIONE}

Entrambi ambientati nella campagna inglese, Between the Acts (1941) di Virginia Woolf e Wigs on the Green (1935) di Nancy Mitford pongono l'attenzione su alcuni degli aspetti più controversi dell'Inghilterra dei turbolenti anni ' 30 del Novecento: la nascita del movimento fascista inglese, la British Union of Fascists di Sir Oswald Mosley, ${ }^{1}$ il deterioramento dei rapporti anglo-germanici e le prime avvisaglie del secondo conflitto mondiale. In questi country-house novel, ${ }^{2}$ gli eventi storici, passati e presenti, fanno irruzione nell'apparentemente tranquillo English countryside e si concretizzano nel pageant, ${ }^{3}$ il fulcro del progetto narrativo. Non è un caso, infatti, che la rievocazione storica sia il fil rouge di diverse opere della letteratura inglese dell'interwar period quali A Glastonbury Romance (1932) di John Cowper Powys, The Rock (1934) di T. S. Eliot, The Abinger Pageant (1934), England's Pleasant Land (1938) di E.M. Forster ${ }^{4}$ e, appunto, Wigs on the Green (1935) di Nancy Mitford e Between the Acts di Virginia Woolf. Come spiega Joshua D. Etsy, il successo del modern pageant-play nell'Inghilterra degli anni ' 30 del Novecento è dovuto a diversi fattori: questo genere anacronistico e neo-tradizionale di matrice edoardiana, ${ }^{5}$ fondato da Louis Napoleon Parker nel 1905 ma che si rifaceva a forme teatrali della Grecia antica e del periodo elisabettiano ${ }^{6}$

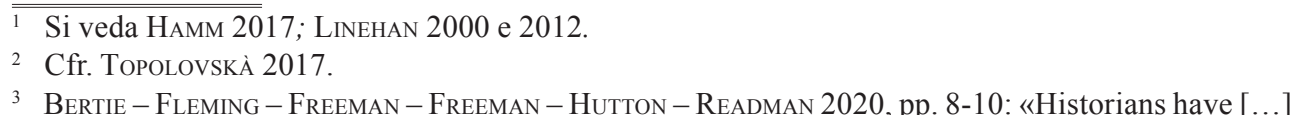
3 Bertie - Fleming - Freeman - Freeman - Hutton - Readman 2020, pp. 8-10: «Historians have [...] identified at least six types of historical pageant during the interwar years. The first of these is the traditional Parker type pageant, generally performed in a relatively small town and with a focus on the intersections of local and national history. [...] A new kind of pageant, performed in the early post-war years, was the ironically named 'pageant of peace', which depicted scenes from the First World War, often involving veterans of the war itself. Alongside the military and imperial uses of pageantry, the form was also adapted by very different political traditions, forming a fourth strand of interwar historical pageants. [...] A fifth strand of interwar pageantry was found in country houses and villages. It was widely depicted in imaginative literature, ranging from highbrow modernism to mass-market paperbacks and even children's books. [...] Finally, many towns and cities staged pageants during the interwar period as a means of promoting the local economy in a period of protracted slump».

4 Si fa riferimento alla seconda parte del volume di ETSY 2009.

5 ETSY 2002, p. 246.

6 Occorre qui fare un breve cenno alla tradizione elisabettiana e giacobiana del pageant come genere funzionale all'autocelebrazione del potere costituito e a forte matrice coloniale e imperiale. Nel periodo elisabettiano, il tema che accomunava tutte le rievocazioni storiche era l'esaltazione del potere incarnato da Elisabetta I, anche - e soprattutto - sul piano mistico e spirituale: la sovrana rappresentava infatti la fonte suprema di autorità, l'unica che potesse rimettere in libertà i prigionieri o i condannati, placare le voci di guerra e procurare rifugio agli indigenti. Richard Grafton ricevette l'incarico da parte della City di organizzare il pageant a cui Elisabetta I assistette durante il percorso verso Westminster Abbey per l'incoronazione: i temi scelti furono alcuni avvenimenti della storia inglese recente e della cultura politica che celebrassero il «Tudor royal imperialism» e la «godly Reformation»; infatti Elisabetta I aveva ereditato dal padre e dal fratello il «mantle of imperial kingship». I pageant successivi rispondono agli auspici impliciti nella coronation royal entry del 1559, come si evince dalla glorificazione di Elisabetta I per opera dei pageant-dramatist. Vedi Merritt 2018, p. 141 e Bergeron 1971, p. 11. I pageant dell'età giacobiana erano anch'essi delle processioni organizzate secondo una gerarchica ben precisa e volte a definire la superiorità del monarca in relazione alla posizione, nonché al ruolo, di ciascun partecipante. Inoltre, tali rievocazioni storiche conferivano a Giacomo I moltepli- 
e persino all'epicità del teatro brechtiano, ${ }^{7}$ era, in prima istanza, la perfetta incarnazione dei «rural and antiquarian ideals of Englishness» ${ }^{8}$ che si stavano rafforzando proprio in quella decade. In secondo luogo, esso assurgeva a simbolo di un'armonia insulare interclassista in un'Europa in cui le masse si affermavano con sempre maggior vigore; faceva inoltre da portavoce della «folk consciousness» $\rangle^{9} \mathrm{e}$, non in ultimo, da cardine su cui si imperniava il nazionalismo civico inglese, espressione di quello spirito collettivo che unisce gli individui. ${ }^{10} \mathrm{~A}$ giudizio di Etsy, la chiave di lettura di questo genere risiede nel fatto che esso rappresenta una serie precisa di eventi storici in ordine cronologico per mostrare «the absence of historical change»: ${ }^{11}$ il pageant infatti mette in scena il susseguirsi di avvenimenti della storia inglese nel corso dei secoli al fine di sottolineare, per utilizzare un'espressione di gattopardiana memoria, come «tutto cambi perché nulla cambi», ${ }^{12}$ riducendo così il fluire lineare del tempo a una mera «seductive symbolic continuity of rural folkways and national traditions», ${ }^{13}$ a una vera e propria «amnesia in fancy dress». ${ }^{14}$ Questo avviene in entrambi i pageant descritti nelle opere di Mitford e Woolf, seppur in modo eterogeneo: è perciò opportuno introdurre i romanzi delle due scrittrici per poi passare alla disamina del ruolo che la rivocazione storica riveste all'interno di esse.

\section{Pageant, imperialismo e fRammentazione in Between The Acts}

Concepito nell' aprile del $1938^{15}$ e terminato il 23 novembre $1940,{ }^{16}$ pochi mesi prima del suicidio di Woolf nel fiume Ouse, nei pressi del paesino di Rodmell, nel Sussex, nel quale si era traferita a causa dei bombardamenti su Londra, ${ }^{17}$ Between the Acts,

ci motivi della mitologia imperialista elisabettiana, in modo tale che venisse mostrata la continuità tra i due regni. Si veda Shohet 2019, p. 150 e CuRtis 1997, p. 157.

7 Shackleton 2017, p. 342.

8 ETsY 2002, p. 246.

9 Ibidem.

10 Ivi, p. 247: «At a time when the masses were asserting themselves on both the literary and political stages of Europe, pageantry was refitted to serve as the genre of insular and interclass harmony. Pageants were the putative vessels of folk consciousness, of a knowable community's midsummer daydreams. Moreover, the pageant-play was perfectly suited to the tenets of English civic nationalism: it seemed likely to promote and express just enough collective spirit to bind people together $[\ldots]$ ».

11 Ivi, p. 249.

12 Si fa riferimento alla celebre frase pronunciata da Tancredi Falconeri, nipote del principe di Salina, nel romanzo Il Gattopardo: «se vogliamo che tutto rimanga com'è, tutto deve cambiare» (ToMASI Di LAMPEDUSA 2002, p. 41).

13 Etsy 2002, p. 249.

14 Ivi, p 250.

15 È opportuno sottolineare come già nell'agosto del 1937 Woolf avesse ritrovato la sua vena creativa: "Will another novel ever swim up? If so, how? The only hint I have towards it is that it's to be dialogue: and poetry: and prose; all quite distinct. No more long closely written books. [...] This morning I had a moment of the old rapture - think of it! [...] And I at once begin making up adventures - ten days of adventures $-[\ldots] \gg($ BLoom 1986, p. 146).

16 TAYLOR 2018, p. 186.

17 Wood 2013, p. 1: «[...] as World War II raged on, German air raids were [...] demolishing the city- 
dapprima intitolato Pointz Hall, ${ }^{18}$ fu pubblicato postumo nel 1941. Quest'ultimo romanzo della scrittrice inglese, le cui vicende si dipanano in una giornata del giugno 1939, è permeato di un senso di angoscia provocato dagli eventi storici che interessavano l'Inghilterra e l'Europa proprio in quegli anni, tra i quali la crisi di Monaco, la dichiarazione di guerra, la caduta di Parigi, la battaglia d'Inghilterra e il Blitz. ${ }^{19}$ Gioca un ruolo rilevante l'ambientazione rurale del romanzo, la quale mette in luce la funzione che l'English countryside assume in diverse opere della letteratura britannica dell'interwar period: ${ }^{20}$ la campagna inglese non appare più come quel paradiso di pace e armonia descritto da alcuni autori vittoriani ed edoardiani, ${ }^{21}$ ma diventa un rifugio fisico dalla guerra incombente e il custode di una tradizione inglese e di una Englishness diverse, svincolate dalla lettura imperialista britannica del passato nazionale. ${ }^{22}$ Il luogo attorno al quale si snoda la narrazione - e il pageant - è Pointz Hall, il country estate della famiglia Oliver che si trova in «the heart of the country» ${ }^{23} \mathrm{e}$ che viene presentato dall'io narrante all'inizio del romanzo come la tipica casa inglese di campagna di medie dimensioni e dall'atmosfera semplice, casalinga:

Pointz Hall was seen in the light of an early summer morning to be a middle-sized house. It did not rank among the houses that are mentioned in guide books. It was too homely. But this whitish house with the grey roof, and the wing thrown out at right angles, lying unfortunately low on the meadow with a fringe of trees on the bank above it so that the smoke curled up to the nests of the rooks, was a desirable house to live in. ${ }^{24}$

In realtà, tale dimora rurale cela diverse contraddizioni storiche. A dispetto della tradizione inglese, la casa è rivolta a nord anziché a sud: «Why, Bart, did they build the house in the hollow, facing north?»; ${ }^{25}$ nonostante sia il 1939, l'arredamento risale all'epoca vittoriana: «The furniture was mid-victorian, bought at Maples, perhaps, in the

scape [...]. Her London home at 37 Mecklenburgh Square was hit by a bomb explosion on 18 September 1940. 'Another bad raid' the following night 'smashed' Oxford street, the British Museum forecourt, 'all [her] old haunts' (D 5: p. 323)».

18 VANDiVERE - Hicks 2016, p. 203.

19 ZwerdLING 1986, p. 302.

20 Oltre ai romanzi di Virginia Woolf e Nancy Mitford qui presi in considerazione, si considerino le opere di altri scrittori e scrittrici britannici dell'interwar period quali Daphne du Maurier, Elizabeth Bowen, Evelyn Waugh e P.G. Wodehouse.

21 Brassley - BurchardT - Thompson 2006, p. 86.

22 ETsY 2009, p. 90: «Like many other English intellectuals in the 1930s, Woolf seems interested in trying to reclaim English tradition [...] from an imperial Britishness that had appropriated the national past».

23 Woolf 1992, p. 25 e RYAN - BolaKi 2012, p. 168: «[...] Woolf's ambiguous use of the phrase 'heart of the country' [...] could either refer to Pointz Hall's literal distance from the city, or suggest that the region of the novel symbolizes a kind of idealized Englishness, the heart of the country itself.» Si può inoltre ipotizzare come questa espressione sia un richiamo da parte di Woolf del titolo del famoso saggio del 1906 di Ford Madox Ford, The Heart of the Country. A Survey of a Modern Land.

24 Woolf 1992, p. 7.

25 Ivi, p. 8. 
forties», ${ }^{26}$ nella biblioteca della casa i classici sono mescolati a volumi sull'irrigazione o sulle malattie dei cavalli: «[...] he stood in front of his country gentleman's library. Garibaldi; Wellington; Irrigation Officers' Reports; and Hibbert on the Diseases of the Horse $\gg{ }^{27}$ o persino a best-seller acquistati da visitatori di Pointz Hall per passare il tempo durante il viaggio in treno verso quella remota località rurale e poi lì dimenticati: «[...] as the train took over three hours to reach this remote village in the very heart of England, no one ventured so long a journey, [...], without buying a book on a bookstall. $[\ldots]$ the shuffle of shilling shockers that weekenders had dropped». ${ }^{28}$

Pointz Hall, la cui ubicazione resta avvolta da un'aura di vaghezza e di mistero per tutta la narrazione («They were so far from the sea. A hundreds miles away, Mrs Swithin said; no, perhaps a hundred and fifty» $)^{29}$ è solo uno degli esempi delle case descritte nei romanzi woolfiani, le quali sono il riflesso di diverse versioni della tradizione della English country house, poiché esaltano o, al contrario, ribaltano i suoi valori di armonia e continuità. ${ }^{30}$ Leena Kore Schröder evidenzia come in Between the Acts Woolf, consapevole dello status ormai mitico della casa di campagna inglese, contribuisca alla costruzione di un'immagine malinconica di essa, non come slancio emozionale verso un passato idilliaco, ma come rivelazione della diversità di tutto ciò che le passa attraverso, ${ }^{31}$ offrendo al lettore un romanzo in linea con la country-house tradition, ma invitandolo, allo stesso tempo, a osservare attentamente l'intrecciarsi della sfera pubblica e di quella privata all'interno di essa. ${ }^{32}$

Perciò, sebbene l'ambientazione rurale di Between the Acts sembri richiamare la cultura di una vecchia Inghilterra «rural rather than industrial, feudal rather than democratic and simple rather than complex, and above all, unified $»^{33}$ - più immaginaria che reale - in cui il paesino di campagna rappresenta l'unico esempio possibile di comunità stabile, in quanto depositario della tradizione inglese e ultimo baluardo contro le forze distruttive del presente, ${ }^{34}$ non bisogna dimenticare "l'operazione di ribaltamento" implicita nella dinamica testuale e quindi la decostruzione di una tradizione letteraria qui restituita come luogo dell'inganno storico e di una retorica populista che la scrittrice va via via denunciando.

Il punto focale della narrazione resta però il village pageant sia, com'è già stato precedentemente osservato, per la sua funzione di simbolo della storia nazionale, della

\footnotetext{
26 Ivi, p. 44.

27 Ivi, p. 71.

28 Ivi, p. 13.

29 Ivi, p. 20.

30 «Gina Wisker maintains that Woolf's houses reflect versions of what she calls 'the English country house tradition', as they 'emphasise values of continuity and harmony, or undercut and question them'». (Miller 2018, p. 5 in DeGay - Breckin - Reus 2018, p. 67).

31 SCHRÖDER 2006, p. 270: «Woolf constructs the nostalgic image of the English country house in full awareness of its status as myth. She invokes the country house image not as an empty emotional gesture towards some idyllic past, but in order to reveal the diversity of what flows through it».

32 Miller 2018, in DeGAY - BRECKIN - Reus 2018, p. 67.

33 ZwERDLING 1977, p. 226.

34 Ibidem
} 
tradizione e di una Englishness rivisitate, ma anche, e soprattutto, come manifestazione di quella duplice capacità del teatro di mostrare l'unità $\mathrm{o}$, al contrario, la disunità del reale. ${ }^{35}$ Organizzato da Miss La Trobe, alter-ego romanzesco di Virginia Woolf e personaggio centrale del romanzo, ${ }^{36}$ il pageant mette in scena episodi della storia letteraria inglese («'Scenes from English history,' Mrs. Manresa explained to Mrs. Swithin. [...] 'Merry England'») $)^{37}$ a partire dal Rinascimento e Shakespeare, passando per le commedie del periodo della Restaurazione e i melodrammi vittoriani, per arrivare fino agli anni '30, periodo in cui sono ambientate le vicende narrate. È necessario però sottolineare come Woolf ribalti lo scopo principale dell'Empire Day pageant tradizionale, ${ }^{38}$ ossia la celebrazione del passato glorioso dell'Inghilterra - attraverso la presentazione della rievocazione storica come una storpiatura caotica di fatti e personaggi - al fine di mettere in discussione il potere imperiale, ${ }^{39}$ la «patriarchal narrative of masculine national identity». ${ }^{40}$ Questo intento risulta evidente in diversi passaggi del romanzo, come quando il colonnello Mayhew si mostra deluso dal fatto che l'esercito inglese non venga adeguatamente rappresentato nella rievocazione storica ( ${ }^{\prime}$ Why leave out the British Army? What's history without the Army, eh?'»), ${ }^{41}$ oppure con la scena del pageant relativa alla Age of Reason, in cui viene smascherato pubblicamente il lato più oscuro del colonialismo inglese, ossia la schiavitù: «In distant mines the savages sweat $[\ldots] \gg{ }^{42} \mathrm{Il}$ culmine della satira dell'imperialismo viene però raggiunto con l'entrata in scena della figura di Budge, proprietario di un pub, nei panni di un poliziotto vittoriano che proclama le meraviglie dell'impero mentre dirige il traffico cittadino, mostrando così, come afferma David Shackleton, la complicità tra patriarcato e autorità coloniale, tema già ampiamente trattato da Woolf in Three Guineas (1938):43

It was Budge the publican; [...]. He wore a long black many caped cloak; waterproof; shiny; of the substance of a statue in Parliament Square; a helmet which suggested a policeman; a row of medals crossed his breast; and in his right hand he held extended a special constable's baton [...]. Budge extended his truncheon and spoke: It ain 't an easy job, directing the traffic [...] of 'Er Majesty's Empire. The Shah of Persia; Sultan of Morocco; or it may be 'Er Majesty in person; or Cook's tourists; black men; white men; sailors, soldiers; crossing the ocean; to proclaim her Empire; all of 'em Obey the Rule of my truncheon. But my job don't end there. I take under my protection and direction the purity and security of all Her Majesty's minions; in all parts of her dominions; insist that they obey the laws of God and Man. [...] Go to Church on Sunday; on Monday, nine sharp, catch the City Bus. ${ }^{44}$

\footnotetext{
35 Ezell 2018, p. 3.

36 HARKer 2011, p. 443.

37 Woolf 1992, p. 51.

39 Shackleton 2017, p. 357.

40 Benziman 2006, p. 61.

41 WoOLF 1992, p. 94.

42 Ivi, p. 75.

43 Shackleton 2017, p. 358.

44 Woolf 1992, pp. 96-97.
}

38 Wood 2013, p. 143: «In the 1930s pageants were still often represented on the Empire Day (24 May), the birthday of Queen Victoria. These plays became a communal method of chronicling English history from Roman times to the Revolution $[\ldots] »$. 
Il disastroso esito finale del pageant è prevedibile fin dallo scompiglio del prologo, quando gli spettatori non riescono a raccapezzarsi se la rappresentazione sia o no iniziata e se debbano rivolgere lo sguardo verso i cespugli o sul palco che è inizialmente vuoto, ma su cui poi compare un'attrice che rappresenta l'Inghilterra e che si dimentica le battute: ${ }^{45}$

Then the play began. Was it, or was it not, the play? [...] All looked at the bushes. For the stage was empty. [...], a small girl, like a rosebud in pink, advanced; [...]: - Gentles and simples, I address you all [...] So it was the play then. Or was it the prologue? Come hither for our festival (she continued) / This is a pageant, all may see / Drawn from our island history. / England am I... - 'She's England,' they whispered. 'It's begun.' 'The prologue,' they added, looking down at the programme. 'England am I,' she piped again; and stopped. She had forgotten her lines. ${ }^{46}$

La musica che dovrebbe accompagnare gli atti è coperta dal frastuono di un macchinario probabilmente rotto, le voci del coro dei paesani, emblema della ripetizione e dei ricorsi storici anziché di cambiamento ${ }^{47}$ non vengono udite dal pubblico. Frammentazione e disgregazione fanno capolino sulla scena, rafforzate dall'immagine di apertura di un'Inghilterra debole, emaciata, lontana dai giorni d'oro dell'Impero britannico, incarnata nella figura minuta di Phyllis Jones, le cui battute mettono in evidenza la condizione di insularità del Regno Unito, apparentemente tagliato fuori dal continente sia a livello geografico che politico: ${ }^{48}$

[...] 'A child new born,' - Phyllis Jones continued, - Sprung from the sea / Whose billows blown by mighty storm / Cut off from France and Germany / This isle. - [...] Chuff, chuff, chuff, the machine buzzed. A long line of villagers in shirts made of sacking began passing in and out in single file behind her between the trees. They were singing, but not a word reached the audience. - England am I, Phyllis Jones continued, facing the audience, Now weak and small [...]. Chuff, chuff, chuff, went the machine like a corn-cutter on a hot day. The villagers were singing, but half their words were blown away. [...] The words petered away. Chuff, chuff, chuff, the machine ticked. ${ }^{49}$

Questo disordine disarmonico che caratterizza il pageant (e l'intero romanzo) è il riflesso del clima di tensione che pervadeva l'Inghilterra e l'Europa di quegli anni e che sarebbe sfociato nella guerra; infatti numerosi riferimenti a essa fanno la loro comparsa tra le pagine, come, per esempio, la doppia ora legale estiva introdotta temporaneamente solo durante il secondo conflitto mondiale: ${ }^{50}$ «[...] the sun's not so hot... That's one good the war has brought us - longer days... ${ }^{51}$ oppure la presenza di aerei in formazione da combattimento nei cieli inglesi: «Twelve aeroplanes in perfect for-

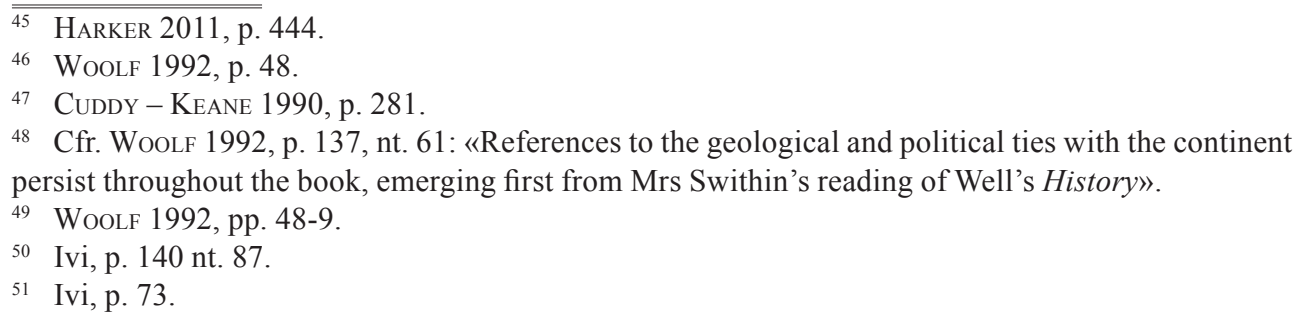


mation like a flight of wild duck came overhead». ${ }^{52} \mathrm{Nel}$ bel mezzo di questa dispersione caotica, i personaggi del romanzo sembrano cercare - invano - l'unione, come si evince dal pronome personale we utilizzato dal coro che fa da sottofondo a tutte le epoche storiche della rappresentazione e che, a giudizio di Alex Zwerdling, dimostra come continui a esistere quell'essential England che cerca strenuamente di sopravvivere anche nei periodi di divisione interna e di confronto internazionale: ${ }^{33}$ "Digging and delving (they sang), hedging and ditching, we pass... Summer and winter, autumn and spring return... All passes but we, all changes... but we remain forever the same». ${ }^{54}$

Ed è proprio il pageant che, sebbene rappresenti da un lato la tensione tra creazione artistica e il caos della realtà, la combinazione paradossale di «repeated certainties and historical clichés with spontaneous improvised and unrepeatable expressions of the present moment, injected through Miss La Trobe's transgressions», ${ }^{55}$ diventa lo stimolo necessario agli spettatori per cercare di ritrovare l'unità, per rimettere insieme i tasselli e ricreare, così, quel senso di comunità ormai perduto: ${ }^{56}$ " 'Scraps, orts and fragments! Surely, we should unite?'». ${ }^{57}$ Miss La Trobe allora non è più solo la sceneggiatrice e la regista del pageant, ma una sorta di Virgilio dantesco del ventesimo secolo (nonostante il suo status ambiguo di estranea, straniera e lesbica), la guida spirituale del suo pubblico - attraverso la rievocazione storica - verso una comprensione del testo in chiave di narrazione storica anti-patriarcale. Ella, infatti, prova a svelare agli spettatori, lungo il susseguirsi delle scene, la loro vera identità, fondamentale per ritrovare il valore più profondo di comunione sociale, come evidenzia Benziman:

She gives them an opportunity to form an identity, and her maternal function emphasizes the fact that the novel presents the community as a huge individual, a collective psyche that needs narratives and imagination in order to obtain memory, and needs memory in order to know who it is. [...] She [...] stands there by the stage, and lends her own voice to certain lines; lines that seem to have great significance in terms of the collective self being represented; lines that, despite their importance, cannot be uttered by the performers without some help. ${ }^{58}$

La Trobe però non riesce nel suo intento, la sua posizione di autorità viene continuamente messa in discussione a causa della tensione che si crea con il pubblico e il pageant si conclude con la dispersione degli astanti che non solo si sono mostrati distratti durante tutta la rappresentazione, ma non sono stati nemmeno capaci di comprendere il significato della rievocazione storica: «'Did you understand the meaning? Well, she said she meant we all act all parts...'». ${ }^{59}$

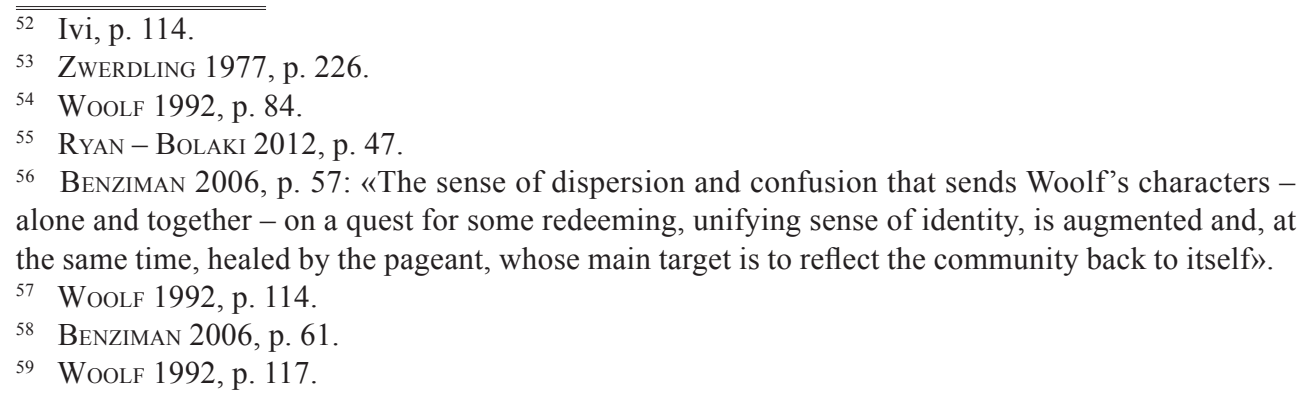


Emblematico è l'ultimo sketch, Present Time, Ourselves, in cui il pubblico diventa protagonista della scena, spettatore della propria immagine riflessa in specchi tenuti in mano dagli attori. L'io che si frantuma in una pluralità di parti viene a rappresentare la condizione umana nel mondo moderno, contraddistinta dalla solitudine e da una perdita irreversibile dell'alto valore che il concetto di consorzio umano e di unità sociale aveva rivestito in epoche passate come, per esempio, nel Medioevo: ${ }^{60}$

Look! Out they came. [...] Holding what? [...], that's the cheval glass from the Rectory! And the mirror that I lent her. My mother's. Cracked. What's the notion? Anything that's bright enough to reflect, presumably, ourselves? Ourselves! Ourselves! Out they leapt, jerked, skipped. Flashing, dazzling, dancing, jumping. Now old Bart... he was caught. Now Manresa. Here a nose... There a skirt... Then trousers only... Now perhaps a face... Ourselves? But that's cruel. To snap us as we are, before we've had time to assume... And only, too, in parts... That's what's so distorting and upsetting and utterly unfair. Mopping, mowing, whisking, frisking, the looking glasses darted, flashed, exposed. [... $]^{61}$

Le barriere tra realtà e finzione si dissolvono in questa scena in cui la frammentazione dell'io è ormai completa e ogni sforzo per ritrovare la comunione sociale risulta vano.

Il triste compito di chiudere la rappresentazione spetta al grammofono, che ha scandito gli intervalli tra le scene e, allo stesso tempo, lo scorrere del tempo ${ }^{62}$ («Tick, tick, tick, the machine continued. Time was passing. The audience was wandering, dispersing. Only the tick tick of the gramophone held them together») ${ }^{63}$ Sempre il grammofono, da strumento necessario ai leader carismatici per trasformare un gruppo di individui in un gregge e tenerlo sotto controllo attraverso autorevoli messaggi patriottici ritmati e rimati, è qui reso da Miss La Trobe un mezzo di contraffazione di tali messaggi per interrompere l'«imperialism of perfect communication». ${ }^{64} \mathrm{~A}$ esso non resta altro che fugare ogni speranza di unione e lasciare spazio a un senso di frammentarietà e di vuoto, presagio di sventura per l'intera civiltà occidentale:

The music chanted: Dispersed are we. It moaned: Dispersed are we. It lamented: Dispersed are we $[. .$.$] Dispersed are we, the music wailed. Dispersed are we. [...] To the valediction$ of the gramophone hid in the bushes the audience departed. [...] The gramophone was affirming in tones there was no denying, triumphant yet valedictory: Dispersed are we; who have come together. But, the gramophone asserted, let us retain whatever made that harmony. [...] Dispersed are we, the gramophone repeated. [...] Dispersed are we, the gramophone informed them. [...] Dispersed are we, the gramophone triumphed, yet lamented. Dispersed are we... [...] The gramophone gurgled Unity - Dispersity. It gurgled Un... dis... And ceased. ${ }^{65}$

Non si assiste quindi solo a una scomparsa graduale del senso di unità, ma sembra che l'incedere del Vecchio Continente verso il secondo conflitto mondiale vada di pari passo con una lenta e inesorabile degenerazione della cultura europea, come osserva

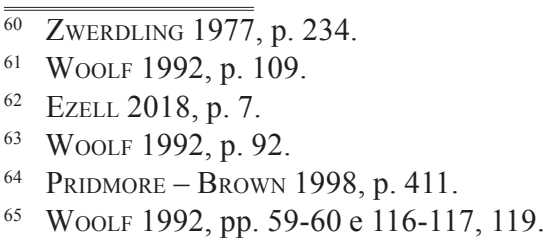


Alex Zwerdling: «It is as if Western culture had been dissected and then stuck together again in random order to form a freakish organism with no chance of life». ${ }^{66} \mathrm{Il}$ caos che caratterizza la rievocazione storica non è altro che il riflesso della realtà disarmonica dell'interwar period, di un mondo che si avvia verso la catastrofe finale, come dimostra l'ultimo atto del pageant, in cui le parole degli attori riapparsi sulla scena («Queen Bess, Queen Anne; and the girl in the Mall; and the Age of Reason; and Budge the policeman. [...] And the pilgrims. And the lovers. And the grandfather's clock. And the old man with a beard. They all appeared»), ${ }^{67}$ che dovrebbero simboleggiare la vitalità culturale di un tempo, non producono altro che confusione: "I am not (said one) in my perfect mind... Another, Reason am I... And I? I'm the old top hat... Home is the hunter, home from the hill... Home? Where the miner sweats, and the maiden faith is rudely strumpeted... Sweet and low; sweet and low, wind of the western sea... Is that a dagger that I see before me? [...]'». ${ }^{68}$

Il pageant, tentativo di Miss La Trobe e della sua creatrice di tracciare quel «pervasive sense of fragmentation and isolation in the modern world to its historical roots ${ }^{69}$ è concluso, il pubblico si disperde, ognuno va per la propria strada. Scende il sipario sulla storia fino ad allora conosciuta e ci si prepara ad affrontare un nuovo atto che non è messo in scena da La Trobe, bensì da menti voraci, affamate di dominio planetario. Ombre di violenza, di sangue e di morte - il sangue che schizza sulla tela della scarpa da tennis di Giles quando calpesta un serpente intento a mangiare un rospo, un insieme mostruoso, una creatura innaturale ${ }^{70}$ e che rimane lì, senza che nessuno lo noti, per tut-

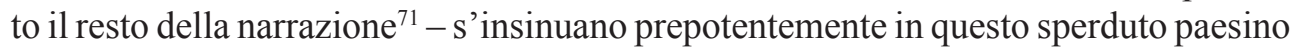
di campagna, simbolo dell' Inghilterra rurale e dell'Inghilterra tutta, per diventare, da lì a pochissimi anni, protagoniste indiscusse degli equilibri storico-politici mondiali. L'orchestra di pace forzata e di appeasement $t^{72}$ diretta da Neville Chamberlain - con scarso successo - ha smesso di suonare, il pubblico non applaude, la melodia lascia spazio al rombo di aerei nemici nei cieli inglesi e al lungo fischio delle bombe che, precipitando, raderanno al suolo intere città, da Coventry fino all'estremo nord, la lontana Clydebank, in Scozia. ${ }^{73}$ Similmente a quanto accade ai personaggi del romanzo, un senso di crescente angoscia e paura, acuito dagli orrori della guerra e dalla minac-

\footnotetext{
$\overline{\overline{66} \text { ZWERDLING } 1977}$, p. 232.

67 Woolf 1992, p. 110.

68 Ivi, pp. 215-216.

69 ZWERDLING 1977, p. 232.

70 Woolf 1992, p. 61: «[...] couched in the grass, curled in an olive green ring, was a snake. Dead? No, choked with a toad in its mouth. The snake was unable to swallow, the toad was unable to die. A spasm made the ribs contract; blood oozed. It was birth the wrong way round - a monstrous inversion. So, raising his foot, he stamped on them. The mass crushed and slithered. The white canvas on his tennis shoes was bloodstained and sticky. But it was action. Action relieved him».

71 Ezell 2018, p. 1.

72 Si veda McDonough 1998, in particolare la parte introduttiva relativa al dibattito sulla appeasement policy di Chamberlain e i capitoli 5 e 6.

73 Per una panoramica sui bombardamenti delle città inglesi durante il Blitz: MACLEOD 2010 e FeRGUSON 2014.
} 
cia di un'invasione nazista, pervaderà l'anima della società, offuscando la ragione, turbando le coscienze, disgregando l'unità interiore e portando una delle più famose scrittrici della letteratura inglese a commettere l'atto estremo in quel fiume che, come appuntava l'ingegnere John Smeaton in data 14 settembre 1767, «is much lower in neap than in spring-tides»». ${ }^{74}$

\section{WigS ON THE GREEN E IL PAGEANT COME SATIRA ANTIFASCISTA}

In una lettera inviata il 21 giugno 1935 alla sorella Unity Valkyrie, ${ }^{75}$ fervente nazista e amica intima di Adolf Hitler, Nancy Mitford comunica di aver epurato il suo ultimo romanzo Wigs on the Green, «a romantic comedy that lampoons both the aristocracy and fascism», ${ }^{76}$ da tutte le battute di dubbio gusto sul fascismo o Sir Oswald Mosley, fondatore della British Union of Fascists (BUF), per paura di poter recare offesa all'altra sua sorella, Diana, moglie in seconde nozze di Mosley. Mitford inoltre specifica di aver eliminato alcuni riferimenti espliciti al Führer ed estromesso, come aveva già annunciato in lettere precedenti, ${ }^{77}$ la figura di Captain Jack, caricatura romanzesca di Mosley.

Il fascismo inglese è, infatti, uno dei temi principali attorno a cui ruotano le vicende di Wigs on the Green (1935), romanzo in cui Mitford si appropria della retorica fascista e ne fa una parodia. ${ }^{78}$ Sin dalle prime pagine compaiono le Union Jackshirts, partito fascista immaginario basato sulla BUF di Mosley, organizzate, nel fittizio paesino rurale di Chalford, da Eugenia Malmains, la più ricca ereditiera d'Inghilterra: per cercare di sposarla e mettere così le mani sulla sua ingente eredità, i due protagonisti, Jasper Aspect e Noel Foster, lasciano Londra e si recano nelle Cotswolds. Occorre sottolineare, come è già stato fatto precedentemente per Between the Acts, l'importanza cruciale del rural setting all'interno del romanzo: esso non solo permette al lettore di comprendere pienamente la critica mitfordiana al fascismo inglese, movimento che aveva trovato ampio sostegno nelle comunità rurali ${ }^{79}$ ma mette anche in luce la volontà della scrittrice di unire «the aristocratic sympathies for fascism to the interwar

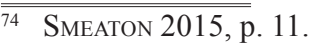

75 Da una lettera di Nancy Mitford alla sorella Unity del 21 giugno 1945: «So now don’t get together with Nardie (nomignolo con cui veniva chiamata Diana in famiglia) \& ban me forever or I shall die. Could you forgive me quite soon? [...] So write quite soon \& say you forgive me. I did take out some wonderful jokes you know \& all the bits about the Captain. OH! DEAR!» (HASTINGS 2012, p. 104).

76 Murphy 2020, p. 16.

77 Dalle lettere che Nancy scrisse a Unity rispettivamente il 7 maggio e il 18 giugno 1935: «[...] I have taken out all reference to the F (ossia Hitler) (not the POF - Mosley -, the other F)»e «My book comes out on $25^{\text {th }}[\ldots]$ I did however hold it up for about a month [...] in order to take out everything which directly related to Captain Jack, amounting to nearly 3 chapters \& a lot of paragraphs. There are now. I think, about 4 references to him \& he never appears in the book as a character at all. In spite of this I am very much worried at the idea of publishing a book which you may object to» (HASTINGS 2012, p. 102).

78 Periyan 2020, p. 47.

79 Stevenson - CoOK 1994, p. 235.
} 
yearning for a return to pastoral and traditional forms of Englishness» ${ }^{80}$ Nella letteratura britannica dell'interwar period, la campagna inglese, il paesaggio rurale, le aree regionali e provinciali diventano una «intermodern quality», veri e propri luoghi di origine o di identità: ${ }^{81}$ per esempio le Cotswolds, regione inglese in cui sono ambientate le vicende e in cui la stessa Mitford aveva trascorso l'infanzia e la giovinezza, vengono descritte da diversi autori inglesi degli anni Venti e Trenta come una versione ideale e idealizzata dell'Inghilterra. ${ }^{82}$ Questa rappresentazione dell'English countryside, «the image of a green and idyllic [...] rural landscape [...] central to ideas of national identity prior to and during the First World War, but $[\ldots]$ under siege between the wars due to disorganized modernization», ${ }^{83}$ è uno dei capisaldi proprio di quel fascismo inglese che propugnava un ritorno alla tradizione rurale, a uno stile di vita semplice, in armonia con la natura, a un mitico «anti-industrial pastoralism», ${ }^{84} \mathrm{e} \mathrm{che}$ si ergeva a unico garante dell'ordine e della stabilità nel caos di quegli anni.

Come è già stato precedentemente anticipato, il fascismo inglese in Wigs on the Green è incarnato dalla figura da Eugenia Malmains, versione romanzesca di Unity Valkyrie, sorella di Nancy. Eugenia, che si rivela fin da subito un'estremista di destra per i suoi discorsi imbevuti di patriottismo e antisemitismo sbraitati in piedi su una vasca da bagno rovesciata in mezzo al village green, decide di organizzare un pageant a Chalford e cerca di imporsi affinché il tema verta su eventi legati alla storia recente del fascismo: ${ }^{85}$ " the March on Rome, the Death of Horst Wessel, the Burning of the Reichstag, $[\ldots]\rangle{ }^{86}$ Dopo essersi scontrata con Noel Forster, il quale invece propende per la messa in scena di una serie di personaggi famosi della storia inglese («Edward I, Florence Nightingale, Good Queen Bess» ${ }^{87}$ ), Eugenia sarà costretta a deviare sulla proposta di Mrs Lace, ossia il reenactement di un avvenimento storico: la visita di re Giorgio III e della regina Carlotta a Chalford nel Settecento («'Pageants [...] must be historical. Now I suggest Charles I and Henrietta Maria's visit to Chalford - it actually happened, you know. They came to Chalford Old Manor, a perfect little Tudor ruin on the edge of the park'»). ${ }^{88} \mathrm{Il}$ vero intento di Eugenia resta però trasformare la rappresentazione storica in un raduno di Unionisti, volto a propagandare idee di stampo fascista $^{89} \mathrm{e}$ a monopolizzare la tradizione per proiettare la sua ideologia estremista. ${ }^{90}$

Il pageant, che coincide con l'acme della narrazione come nell'opera di Woolf, dovrebbe inizialmente prevedere i seguenti cinque episodi: 1) la morte di James Wolfe ${ }^{91}$

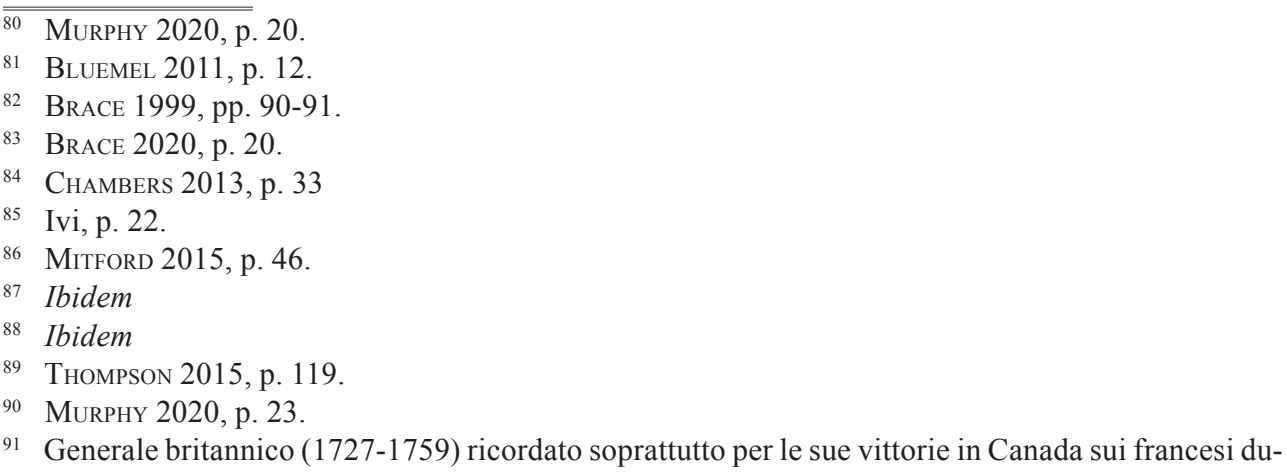


trafitto da una pallottola mentre declama Elegy Written in a Country Churchyard di Thomas Gray in occasione della vittoria sui pacifisti francesi in Québec, preceduta dall'arrivo di re Giorgio III e della regina Carlotta e dal discorso di benvenuto di Lord Chalford, 2) la rievocazione degli avvenimenti legati al Boston Tea Party, 3) le vicende del maggior generale Robert Clive, primo Barone Clive di Passey ${ }^{92}$ e all'impeachment di Warren Hastings ${ }^{93}$ in India; 4) il ritratto di Nelson con il binocolo premuto sull'occhio cieco intento a osservare Lady Hamilton con quello sano mentre gli viene strappato via un braccio, introdotto dall'annuncio dello scoppio della Rivoluzione francese, del ferimento dell'ammiraglio inglese alle Canarie e dalle buone nuove relative alla vittoria della marina di Sua Maestà contro i pacifisti francesi, e, dulcis in fundo, 5) gli ultimi istanti di vita di Nelson su un pagliericcio. Il tutto si dovrebbe concludere con un tableau finale intitolato The Exile of Napoleon e l'esecuzione di God Save the King da parte della banda di ottoni. ${ }^{94}$

Ma, come aveva ben previsto Jasper («'Something awful is going to happen. [...]. I know it'»), ${ }^{95}$ esso si rivela un caos già dal principio tra tragedie sfiorate (la carrozza in cui viaggiano Mr Wilkins nei panni di Giorgio III e Mrs Lace in quelli della regina Carlotta rischia di schiantarsi contro Chalford House, ma viene deviata all'ultimo istante da Wilkins che, salendo sul predellino, tira prontamente le redini) e la totale noncuranza nei confronti della veridicità storica («[...] Jasper had ignored historical truth to a degree unprecedented even in pageantry») ${ }^{96}$ come si può notare dal discorso di Giorgio III, in cui il sovrano si scaglia contro i «vile democrats $»{ }^{97} \mathrm{i}$ quali, a suo giudizio, vogliono mettere sottosopra il «great Empire» ${ }^{98}$ oppure da un altro sketch, in cui il re viene informato da un messaggero che Luigi di Francia è stato rasato a zero da marxisti non ariani. ${ }^{99} \mathrm{La}$ scelta di Mitford di inserire nel romanzo il personaggio di Giorgio III non è affatto casuale, ma serve a far sì che il lettore non prenda sul serio il pageant: ${ }^{100}$ la pazzia di quel sovrano che una volta scambiò un albero del parco di Windsor per Federico II di Prussia ${ }^{101}$ ribalta ogni tentativo di politicizzare la sua figura, trasformando in un tergiversare astruso, privo di capo o di coda, il suo discorso

rante la guerra dei Sette Anni.

92 Conosciuto anche con il cognome di Clive d'India, Robert Clive (1725-1774) fu un pari d'Irlanda e governatore del Bengala, personaggio chiave, insieme a Warren Hastings, nella creazione del British Raj. Si veda KaUl - St. John 2012, pp. 5, 13, 17, 19.

93 Hastings (1732-1818), governatore generale delle Indie Orientali, fu accusato di impeachment da Edmund Burke nel 1787, soprattutto per le intimidazioni rivolte alla Hicky's Bengal Gazette, che si scagliava contro la corruzione della Compagnia delle Indie Orientali. Tornato in Inghilterra, subì un lungo processo, ma fu assolto da tutti i capi d'accusa. Si veda Rolli 2019.

94 Mitford 2015, pp. 150-153.

95 Ivi, p. 154.

96 Ivi, p. 155.

97 Ivi, p. 152.

98 Ibidem

99 Ivi, p. 155.

100 Murphy 2020, p. 22.

101 Spielvogel 2008, p. 339. 
preparato a puntino da Eugenia, in cui racconta ai sudditi di Chalford dell'Inghilterra apparsagli in un sogno profetico come la fanghiglia di una democrazia decadente che i fascisti inglesi vogliono riportare all' antico fulgore. ${ }^{102}$ Il finale comico del pageant viene acuito dal buffo scontro in cui gli esteti pacifisti «dressed as the sanculottes of Revolutionary France and wearing yellow caps on their heads ${ }^{103}$ attaccano $i$ fascisti inglesi al grido di: «We want peace! [...] Kill social Unionism!». ${ }^{104}$ L'apice della scena, che Lady Chalford scambia ingenuamente per un episodio della rievocazione storica, viene raggiunto quando Eugenia, a guisa di una bellissima Giovanna D'Arco novecentesca, si getta nella mischia sventolando fieramente la Union Jack:

Like a whirlwind, Eugenia Malmains dashed into the fray, seizing a Union Jack from off the platform she held it high above her head and with loud cries she rallied the Comrades to her. The Pacifists fell back for a second in amazement, never had they seen so large, so beautiful, or so fierce a woman. That second was their undoing. [...]. The Social Unionists, all rallying to Eugenia, presented at last a united front. Led by her, they shouted their fighting cry: 'We defend the Union Jack.' 'We will whack / And we will smack, / And we will otherwise attack / All traitors to the Union Jack. / For we defend the Union Jack.' and charged again and again into the ranks of the enemy, which were gradually falling away before their determined onslaught. ${ }^{105}$

Lo scontro tra pacifisti e Unionisti, che prende il posto della scena finale del pageant tradizionale in cui gli abitanti assediati, fedeli al re, resistono tenacemente a Cromwell l'usurpatore, ${ }^{106}$ portando così la rievocazione storica ad assumere un tono fascista anziché monarchico, ${ }^{107}$ si può presagire già dal titolo del romanzo. Esso infatti può essere letto su tre livelli: uno letterale, in quanto, durante la rissa, volano realmente parrucche incipriate, parte integrante dei costumi settecenteschi, nel parco di un country estate - l'ambientazione del pageant -, uno più metaforico legato all'espressione wigs on the green, la quale può essere tradotta in italiano con 'botte da orbi' (sempre connessa alla lotta tra fascisti ed esteti pacifisti) e, non in ultimo, un gioco di parole, dove la parola wigs è omofono di Whigs. ${ }^{108}$

Come è stato accennato in precedenza, in Wigs on the Green il pageant coincide con il tentativo di Eugenia di proporre una reinterpretazione della storia britannica in chiave nazionalista, antidemocratica e antipacifista, presentando i principi delle Union Jackshirt come «an extension of English history» ${ }^{109}$ e diventa, per questa ragione, una storpiatura dell'histoire événementielle, in cui «popular culture is co-opted for fascistic ends». ${ }^{110}$ Eliza Murphy evidenzia come la cattiva riuscita del pageant rappresenti

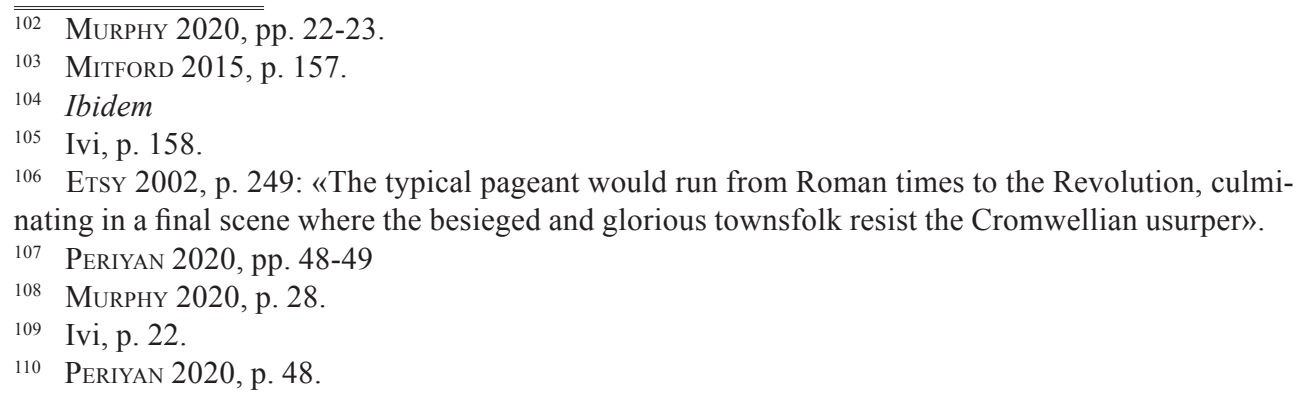


l'attacco più esplicito di Mitford al fascismo inglese, movimento che non solo sembra nascondersi dietro a un falso ritorno alla tradizione, ma che appare anche come un disordine goffo e clownesco anziché come attività politica seria e strutturata. ${ }^{111}$ Anche l'inno intonato dalle Union Jackshirt riunite attorno a Giorgio III, che sembra apparentemente intriso di parole d'odio e di violenza nei confronti degli stranieri, è in realtà una canzonetta piena di luoghi comuni, usata da Mitford per smascherare la vana retorica fascista - condita con cucchiaiate di olio di ricino - sul primato della nazione inglese e sulla difesa della patria, che sarebbe dovuta risorgere dalle ceneri come l'Araba Fenice:

'Onward, Union Jackshirts Fight for England's fame. / Fight and die for England, / Saving her from shame. / When foreigners make grimaces, / Stamp them in the mud, / Jump upon their faces, / Cover them with blood. [...] Onward, Union Jackshirts / England shall win through. / England shall rise greater, / Thanks to Jackshirts true. / Junket fronts shall quiver, / We shall give them more / Reasons to shiver / Than they had before. [...] Fight with shell and bullet, / Fight with castor oil, / Fight with pen and paper, / Fight, Oh Jackshirts loyal. / Fight the loathly Pacifist, / Fight the junket breast, / Make them feel the Jackshirt's fist, [...] / Foreigners you'll whack [...]'. ${ }^{112}$

È forse l'ironia con cui Mitford ha trattato temi scottanti, quali la rapida ascesa della BUF o la decadenza dell'aristocrazia d'Oltremanica, ad aver fatto storcere il naso ai suoi contemporanei ${ }^{113}$ verso i suoi romanzi, come nel caso di Wigs on the Green, giudicato da diversi critici «less a political novel than a 'light, accomplished comedy of manners'». ${ }^{114}$ Anche qui però Mitford non si smentisce e utilizza l'arma pungente della satira per criticare il fascismo inglese - e, di conseguenza, quello europeo - i cui metodi e la cui retorica risultavano, a suo giudizio, esageratamente roboanti. È opportuno però evidenziare come l'autrice riconoscesse il successo oggettivo che nazismo e fascismo avevano ottenuto in Inghilterra e in Europa, come traspare dalla lucida analisi di Jasper Aspect, il quale attribuisce il vasto consenso da loro acquisito al diffuso malessere e scontento sociale nei confronti della politica del tempo: ${ }^{115}$ " $\mathrm{I}$ am inclined to think that the Western civilization we know needs putting out of its agony as soon as possible. It is old and tired, the dark ages are practically upon us anyhow, and I should prefer that they march in with trumpet and flag than that they should creep upon us to the tap of the typewriter'»». ${ }^{116} \mathrm{Si}$ riaffaccia quindi l'idea, presente in Between the Acts, che in quegli anni fosse in atto una decadenza della civiltà occidentale e Mitford «looked back with nostalgia to a vanished past, where a public spirited aristocracy still

\footnotetext{
$\overline{\overline{111} \text { MURPHY 2020, p. }} .22$.

112 Mitford 2015, pp. 156-157.

113 THOMPSOn 2015, p. 122: «Because of this refusal to 'take fascism seriously', Nancy has been called politically naïve: as if the massiveness of the theme was beyond her, and she could only respond to it with mockery».

114 Si veda l'introduzione di Charlotte Mosley all'edizione Penguin di Wigs on the Green del 2010, p. XVI.

115 Periyan 2020, p. 48.

116 Mitford 2015, pp. 98-99.
} 
lived on the land [...] a patrician point of view that threads through much of her writing». ${ }^{17}$ Una senso di nostalgia limitata però ai soli valori della classe sociale a cui apparteneva, la quale viene invece aspramente criticata nei suoi romanzi - sempre attraverso il velo della satira - per le scelte politiche spesso estremiste dei suoi membri, ${ }^{118}$ unito a una profonda malinconia verso quella buona, vecchia Inghilterra immaginaria, in cui la nobiltà rurale viveva nei country estate in modo semplice, modesto e in armonia con la gente comune: un mondo perfetto ma irreale in cui ognuno occupava un posto preciso nella società. ${ }^{119}$ Secondo Judy Suh, Mitford da un lato lega il senso di noia e di pessimismo dell'aristocrazia decadente dell'interwar period a un'iniziale approvazione del fascismo inglese - ed europeo - da parte di molti peer e rispettabili conservatori, mentre dall'altro enfatizza la strumentalizzazione fascista di nuove forme di «commodity culture and cultural simulacra», vedendo nel mitico «country house ethos»- qui inteso come unione di «cosmopolitanism, hospitality, and patronage» - un potenziale antidoto culturale al fascismo. ${ }^{120}$ Charlotte Mosley invece afferma che la scrittrice potesse condividere con il fascismo inglese la teoria secondo cui la società europea avesse bisogno di un cambiamento radicale per arrestare l'inesorabile declino in cui stava precipitando, ma che rimanesse comunque distante dalla visione millenaria delle BUF di una «bright new Britain»: ${ }^{121}$ ciò sembra esser confermato da Mitford stessa in una lettera del 1934 a Diana, in cui arriva persino a sottolineare come Wigs on the Green sia «far more in favour of Fascism than otherwise». ${ }^{122}$ I dubbi però restano vista la sua presa di posizione contro la sorella e Mosley, specialmente negli anni della guerra, anche se tale dichiarazione potrebbe essere, dopotutto, frutto di quell'ironia che caratterizza le sue opere.

\section{Conclusione}

Nonostante le numerose divergenze sostanziali e formali nella trattazione del pageant, il dialogo che si viene a creare tra Woolf e Mitford, «an uncommon pairing», ${ }_{123}$ permette al lettore di riflettere ben oltre le limitanti categorie generazionali, politiche ed estetiche, e di comprendere come la Englishness e la storia nazionale fossero al centro della produzione letteraria di numerosi scrittori inglesi degli anni ' 30 , come emerge dal loro sforzo nel rivedere e ripensare alle narrazioni storiche nazionali nel periodo inter e postbellico. Se si toglie l'etichetta di "modernista" dall'opera di Woolf e di "po-

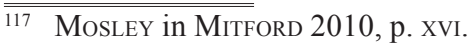

118 Murphy 2020, p. 24.

119 Hastings 2012, p. 113: «[...] her view of English history [...] reveals nothing more nor less than a traditional, true-blue, schoolroom Conservatism, full of nostalgia for The Past as a kind of Gilbertian golden age in which every Englishman knew his place, the lord, a sensible man of ample means and a classical education, living in perfect harmony with the commoner at his gate».

120 SuH 2009, p. 135.

121 Mosley in Mitford 2010, p. XVI.

122 Hastings 2012, p. 103.

123 Delsandro 2014, p. 157.
} 
polare" da quella di Mitford, si scoprono numerosi punti in comune tra le due autrici: sebbene non si possano considerare "alleate" sul piano politico o sociale, entrambe si collocano sulla stessa linea per quanto concerne la visione relativa alle politiche nazionalistiche che caratterizzarono l'interwar period, il crollo della hybris imperiale britannica e il progressivo declino di una stratificazione sociale rigida e fossilizzata. Come si evince da queste due opere, negli anni '30 il pageant diventa uno strumento di cui si servono diversi autori inglesi per esplorare e, allo stesso tempo, criticare la Englishness, offrendo così al lettore un mezzo per oltrepassare le «limitations of scholarly characterization, aesthetic affiliations, and generational categories». ${ }^{124}$

Inoltre, se non è da escludere che Woolf conoscesse il romanzo di Mitford, è invece certo che Mitford conosceva le opere woolfiane, come dimostra un passaggio di Love in a Cold Climate (1949) di Mitford, in cui Fanny, moglie di un emergente don di Oxford, spiega a Lady Montdore che suo marito non crede che le donne possano essere delle intellettuali: «You see, he doesn't believe that women ever are intellectuals, hardly, hardly, ever, perhaps one in ten million - Virginia Woolf perhaps - [...]». ${ }^{125}$ Non bisogna però dimenticare, infine, la grande differenza che intercorre tra il modo dissacrante, sovversivo e scanzonato in cui Woolf rilegge la storia inglese, mettendone in discussione le fondamenta e i valori tradizionali, e la satira di Mitford che è certamente meno incisiva, anche dal punto di vista della scrittura.

Federico Prina

Università degli Studi di Milano federico.prina@unimi.it

\section{RIFERIMENTI BIBLIOGRAFICI}

Benziman 2006 : Galia Benziman, 'Dispersed Are We': Mirroring and National Identity in Virginia Woolf's 'Between the Acts', «Journal of Narrative Theory» 36, 1 (2006), pp. 53-71.

Bergeron 1971 : David M. Bergeron, English Civic Pageantry, 1558-1642, London, Edward Arnold, 1971.

Berti - Freeman - Freeman - Hutton - Readman 2020 : A. Berti, L. Fleming, M. Freeman, A. Hutton, P. Readman, Restaging the Past. Historical Pageants, Culture and Society in Modern Britain, London, UCL Press, 2020.

BLoom 1986 : H. Bloom, British Modernist Fiction, 1920 to 1945, New York, Chelsea House Publishers, 1986.

124 Ibidem

125 Mitford 2001, p. 388. 
Bluemel 2011 : K. Bluemel, Intermodernism, Edinburgh, Edinburgh University Press, 2011.

Brace 1999 : C. Brace, Finding England Everywhere: Regional Identity and the Construction of National Identity, 1890-1940, «Ecumene» 6, 1 (1999), pp. 90-109.

Brassley - Burchardt - Thompson 2006 : P. Brassley, J. Burchardt, L. Thompson, The English Countryside Between the Wars: Regeneration Or Decline?, Martlesham, The Boydell Press, 2006.

Chambers 2013 : C. Iain, Border Dialogues: Journeys in Postmodernity, London-New York, Routledge Revivals, 2013.

Cuddy-Keane 1990 : M. Cuddy-Keane, The Politics of Comic Modes in Virginia Woolf's Between the Acts, «PMLA» 105, 2 (1990), Cambridge, Cambridge University Press, pp. 273-285.

CuRTIS 1997 : L. P. Curtis, The Making of Jacobean Culture: James I and the Renegotiation of Elizabethan Literary Culture, Cambridge, Cambridge University Press, 1997.

Delsandro 2014 : E. Delsandro, "Drawn from Our Island History”: Virginia Woolf, Nancy Mitford and the Politics of Pageantry, in Virginia Woolf and the Common(wealth) Reader: Selected Papers from the Twenty-third Annual International Conference on Virginia Woolf, a cura di H. Wussow, M.A. Gillies, Clemson, Clemson University Press, 2014.

ETsY 2009 : J. Etsy, A Shrinking Island: Modernism and National Culture in England, Princeton, Princeton University Press, 2009.

Eтsу 2002 : J. Etsy, Amnesia in the Fields: Late Modernism, Late Imperialism, and the English Pageant-Play, «English: Journal of the English Association» 69, 1 (2002), pp. 245-276.

Ezell 2018 : B. Ezell, Modern Drama in the Modern Novel: 'Between the Acts', paper presentato alla conferenza «British Women Writer 2018».

Ferguson 2014 : N. Ferguson, The Second World War: A Miscellany, Chichester, Summersdale, 2014.

Ford 1906 : F. M. Ford, The Heart of the Country. A Survey of a Modern Land, London, Alston Rivers, 1906.

Hамм 2017 : J. Hamm, Mosley's Blackshirts: The Inside Story of The British Union of Fascists 1932-1940, London, Black House Publishing, 2017.

Hastings 2012 : S. Hastings, Nancy Mitford, New York, Random House, 2012.

HARKer 2011 : B. Harker, 'On different levels ourselves went forward': Pageantry, Class Politics and Narrative Form in Virginia Woolf's Between the Acts, «English: Journal of the English Association» 78, 2 (2011), pp. 433-456.

Linehan 2000 : T. P. Linehan, British Fascism, 1918-39: Parties, Ideology and Culture, Manchester, Manchester University Press, 2000.

LineHAN 2012 : T. P. Linehan, East London for Mosley: The British Union of Fascists in East London and South-West Essex 1933-40, London, Frank Cass, 2012. 
MacLeod 2010 : J. MacLeod, River of Fire: The Clydebank Blitz, Edinburgh, Birlinn Limited, 2010 .

McDonough 1998 : F. McDonough, Neville Chamberlain, Appeasement and the British Road to War, Manchester, Manchester University Press, 1998.

Merritt 2018 : J.F. Merritt, 'Under the Shadowe of the Church?'The Abbey and the town of Westminster 1530-1640, in Westminster Abbey Reformed: 1540-1640, ed. by C.S. Knighton, R. Mortimer, London-New York, Routledge, 2018.

Miller 2018 : M.A. Miller, Through the Arch: The Country House and the Tradition of English Tyranny in Woolf's Between the Acts, in J. DeGay, T. Breckin, A. Reus, Virginia Woolf and Heritage, Clemson, Clemson University Press, 2008, pp. 62-72.

Mitford 2001 : N. Mitford, Love in a Cold Climate, London, Penguin, 2001 (I ed. 1949).

Mitford 2015 : N. Mitford, Wigs on the Green, London, Penguin, 2015 (I ed. 1945).

Murphy 2020 : E. Murphy, Fascism, Comedy, and Weak Commitments in Nancy Mitford's Wigs on the Green, «Feminist Modernist Studies» 3, 1 (2020), pp. 16-31.

KaUL - St. John 2012 : C. Kaul, I. St. John, The Making of the Raj: India Under the East India Company, Westport, Praeger Publishers, 2012.

PAGEtTI 2014 : C. Pagetti, “Where there's a Will, there's a Way": il dialogo tra Virginia Woolf e Master William in Will the Modernist: Shakespeare and the European Historical AvantGardes, ed. by G. Cianci, C. Patey, Bern, Peter Lang, 2014.

Periyan 2020 : N. Periyan, Pacifism, Fascism and the Crisis of Civilization: Vera Brittain, Storm Jameson and Nancy Mitford in the 1930s, in British Women's Writing, 1930 to 1960: Between the Waves, ed. by J. Thomas, S. Kennedy, Liverpool, Liverpool University Press, 2020, pp. 37-52.

Pridmore-Brown 1998 : M. Pridmore-Brown, 1939-40: Of Virginia Woolf, Gramophones, and Fascism, «PMLA» 113, 3 (1998), pp. 408-421.

Rolli 2019 : C. Rolli, The Trial of Warren Hastings: Oratory and Reception in EighteenthCentury England, London, Bloomsbury, 2019.

Ryan - Bolaki 2012 : D. Ryan, S. Bolaki, Contradictory Woolf: Selected Papers from the Twenty-First Annual International Conference on Virginia Woolf, Clemson, Clemson University Press, 2012.

SCHRÖDER 2006 : L. Kore Schröder, 'The Lovely Wreckage of the Past': Virginia Woolf and the English Country House, «English: Journal of the English Association» 55, 213 (2006), pp. 255-280.

Shackleton 2017 : D. Shackleton, The Pageant of Mutabilitie: Virginia Woolf's Between the Acts and The Faerie Queene, «The Review of English Studies», 68, 284 (2017), pp. 342-367. 
Sнонет 2019 : L. Shohet, Pageants, Masques, and Entertainments: Old Rituals, New Forms, in Gathering Force: Early Modern British Literature in Transition, 1557-1623, ed. by K. Poole, L. Shohet, Clemson, Clemson University Press, 2019.

Smeaton 2015 : John F. Smeaton, Reports of the Late John Smeaton F.R.S., Made on Various Occasions, in the Course of His Employment as a Civil Engineer, London, Arkose Press, 2015 (I ed. 1837).

Spielvogel 2008 : J. Spielvogel, Western Civilization: A Brief History, Volume II: Since 1500, Belmont, Wadsworth Publishing Company, 2008.

Stevenson - Cook 1994 : J. Stevenson, C. Cook, Britain in the Depression: Society and Politics: 1929-1939, London- New York, Longman, 1994, p. 235.

Sun 2009 : J. Suh, Fascism and Anti-Fascism in Twentieth-Century British Fiction, LondonNew York, Palgrave Macmillan, 2009.

TAYLOR 2018 : M. C. Taylor, Last Works: Lessons in Leaving, New Haven, Yale University Press, 2018.

Thompson 2015 : L. Thompson, Life in a Cold Climate: Nancy Mitford The Biography, New York, Pegasus Books, 2015.

Tomasi di Lampedusa 2002 : G. Tomasi di Lampedusa, Il Gattopardo, Milano, Universale Economica Feltrinelli, 2002 (I ed. 1958).

ToPOLOvskà 2017 : T. Topolovskà, The Country House Revisited: Variations on a Theme from Forster to Hollinghurst, Prague, Karolinum Press, 2017.

VAndivere - Hicks 2016 : J. Vandivere, M. Hicks, Virginia Woolf and Her Female Contemporaries, Clemson, Clemson University Press, 2016.

Wood 2013 : A. Wood, Virginia Woolf's Late Cultural Criticism: The Genesis of "The Years", "Three Guineas" and "Between the Acts", London, Bloomsbury Academic, 2013.

Woolf 1992 : V. Woolf, Between the Acts, London, Penguin, 1992 (I ed. 1941).

Zwerduing 1986 : A. Zwerdling, Virginia Woolf and the Real World, Oakland, University of California Press, 1986.

ZwerdLING 1977 : A. Zwerdling, 'Between the Acts' and the Coming of War, «NOVEL: A Forum on Fiction» 10, 3 (1977), pp. 220-236. 